\title{
PENGARUH SUHU REAKSI, KECEPATAN PENGADUKAN DAN WAKTU REAKSI PADA PEMBUATAN SABUN PADAT DARI MINYAK KELAPA (Cocos nucifera L.)
}

\section{EFFECT OF TEMPERATURE REACTION, SPEED OF REACTION AND REACTION TIME IN MAKING SOAP FROM COCONUT OIL (Cocos nucifera L.)}

\author{
Rosdanelli Hasibuan*, Fransiska Adventi, Rahmad Parsaulian Rtg \\ Departemen Teknik Kimia, Fakultas Teknik, Universitas Sumatera Utara, \\ Jalan Almamater, Medan, 20155, Indonesia \\ Email : rosdanelli@gmail.com
}

\begin{abstract}
Abstrak
Sabun adalah pembersih yang dibuat dengan reaksi kimia antara natrium hidroksida atau kalium hidroksida dengan asam lemak dari minyak nabati atau lemak hewani. Sabun dapat dibuat dengan beberapa metode yakni metode saponifikasi dan netralisasi, pada penelitian ini dilakukan dengan metode saponifikasi. Dalam metode saponifikasi terdapat beberpa permasalahan yakni kondisi operasi yang meliputi suhu reaksi, kecepatan pengadukan dan waktu pengadukan. Oleh karena itu, perlu dilakukan penelitian untuk mengetahui kondisi terbaik reaksi penyabunan yaitu kecepatan reaksi, suhu operasi dan waktu reaksi dengan menggunakan impeller jenis multiple pitch blade turbine dengan variabel penelitian suhu reaksi $60^{\circ} \mathrm{C}, 70^{\circ} \mathrm{C}$, dan $80^{\circ} \mathrm{C}$, kecepatan pengadukan 300 rpm, 400 rpm dan 500 rpm dan waktu reaksi 45 menit, 60 menit, dan 75 menit. Reaksi saponifikasi dilakukan dengan memanaskan minyak kelapa dan memasukkan $\mathrm{NaOH} 30 \%$ secara perlahanlahan kemudian diaduk dengan pengaduk multiple pitch blade. Produk akan dianalisa dengan pengujian kadar alkali, kadar air dan $\mathrm{pH}$ sabun. Kondisi operasi terbaik yang diperoleh dari penelitian ini adalah pada suhu suhu $70{ }^{\circ} \mathrm{C}$, waktu reaksi 60 menit, kecepatan pengadukan 400 rpm dengan nilai pH 9,4 dan kadar alkali 0,073 serta kadar air 9,8.
\end{abstract}

Kata kunci: minyak kelapa, multiple pitch blade, sabun, saponifikasi.

\begin{abstract}
Soap is a cleanser made by chemical reactions between sodium hydroxide or potassium hydroxide with fatty acids from vegetable oils or animal fats. Soaps can be made by several methods, namely saponification and neutralization methods, in this study carried out by saponification method. In the saponification method there are several problems namely operating conditions which include reaction temperature, stirring speed and stirring time. Therefore, need to do research to determine the best conditions of saponification reaction, namely reaction speed, operating temperature and reaction time using an impeller type multiple pitch blade turbine with research variables reaction temperature $60^{\circ} \mathrm{C}, 70^{\circ} \mathrm{C}$, and $80^{\circ} \mathrm{C}$, stirring speed $300 \mathrm{rpm}, 400 \mathrm{rpm}$ and $500 \mathrm{rpm}$ and reaction time of 45minutes, 60 minutes, and 75 minutes. Saponification reaction is carried out by heating coconut oil and inserting $30 \% \mathrm{NaOH}$ slowly and then stirring with a multiple pitch blade stirrer. The product will be analyzed by testing alkaline levels, moisture content and $\mathrm{pH}$ of the soap. The best operating conditions obtained from this study were at a temperature of $70{ }^{\circ} \mathrm{C}$, reaction time of 60 minutes, stirring speed of $400 \mathrm{rpm}$ with a pH value of 9.4 and an alkaline level of 0.073 and a moisture content of 9.8 .
\end{abstract}

Keywords : coconut oil, multiple pitch blade, soap, saponification.

\section{Pendahuluan}

Sabun merupakan salah satu produk industri kimia yang sangat dibutuhkan masyarakat Indonesia. Proses pembuatan sabun dapat dibuat dengan cara proses saponifikasi. Proses saponifikasi terjadi karena reaksi antara trigliserida dengan alkali yang menghasilkan produk samping berupa gliserol.

Proses pembuatan sabun tidak terlepas dari proses pengadukan (agitasi), Agitasi (pengadukan) merupakan sebuah proses yang menunjukkan gerakan yang terinduksi menurut cara tertentu pada suatu bahan di dalam bejana dimana gerakan itu biasanya mempunyai semacam pola sirkulasi. Aplikasi agitasi bisa dilakukan dalam sebuah tangki berpengaduk. Proses agitasi umumnya bersinergi dengan proses mixing [12].

Kelapa (Cocos nucifera Linn.) termasuk dalam keluarga Arecaceae dibudidayakan terutama di daerah tropis dengan kelembaban tinggi, curah hujan teratur, dan tanah 
berpasir.Negara-negara seperti India, Sri Lanka, Indonesia, dan Filipina memiliki andil besar dalam produksi kelapa secara global [5].

Saat ini, perkebunan kelapa di Indonesia mencapai 3,8 juta hektar, menghasilkan 3,2 juta ton sebagai kopra, sedangkan lebih dari $90 \%$ merupakan pertanian sipil. Luas perkebunan yang tersebar di wilayah Indonesia, Sumatera memiliki luas wilayah sebesar 33,63\%, Jawa memiliki 22,75\%, Sulawesi memiliki $19,40 \%$, Bali, NTB, dan NTT memiliki 7,70\%, Maluku, Papua 8,89\% dan Kalimantan 7,26\% [3].

Minyak kelapa (Coconut Oil) sebagian besar terdiri dari asam lemak jenuh (Saturated Fatty Acid, SFA), kira-kira $90 \%$ dari komposisi totalnya. Dalam hal nutrisi, satu sendok makan minyak kelapa (13 g) mengandung sekitar 120 kkal, $12 \mathrm{~g}$ lemak total, 11,2 g SFA, 0,7 g asam lemak tak jenuh tunggal (Monounsaturated FattyAcid, MUFA) dan 0,2 g asam lemak tak jenuh ganda (Polyunsaturated Fatty Acid, PUFA). Asam lemak utama (Fatty Acid, FA) yang ditemukan di CO adalah asam laurat (12: 0), myristic (14: 0) dan palmitic (16: 0), masingmasing mewakili 46\%, 17\% dan 9\% FA [19].

Kelapa dan produk sampingnya telah digunakan selama berabad-abad sebagai kosmetik, obat-obatan dan lainnya [1]. Salah satu yang paling banyak dimanfaatkan dari kelapa adalah minyak kelapa, minyak kelapa didefinisikan sebagai minyak yang dihasilkan dari biji kelapa segar dan matang (Cocos nucifera L.) melalui cara mekanis dan alami, baik dengan penggunaan panas atau tidak asalkan tidak menyebabkan perubahan atau transformasi minyak [20]. Minyak kelapa banyak digunakan sebagai bahan baku pembuatan sabun [18].

Teori

Sabun termasuk salah satu jenis surfaktan yang terbuat dari minyak atau lemak alami. Surfaktan mempunyai struktur bipolar, bagian kepala bersifat hidrofilik dan bagian ekor bersifat hidrofobik. Karena sifat inilah sabun mampu mengangkat kotoran (biasanya lemak) dari badan atau pakaian [20] Molekul sabun memiliki rantai hidrokarbon yang panjang dengan gugus asam karboksilat pada satu ujung, yang memiliki ikatan ion dengan ion logam, biasanya natrium atau kalium. Ujung hidrokarbon tidak polar yang larut dalam zat non polar dan ujung ionik larut dalam air [17].

Sabun dibuat dengan dua cara yaitu proses saponifikasi dan proses netralisasi minyak. Proses saponifikasi minyak akan memperoleh produk sampingan yaitu gliserol, sedangkan proses netralisasi tidak akan memperoleh gliserol. Proses saponifikasi terjadi karena reaksi antara trigliserida dengan alkali, sedangkan proses netralisasi terjadi karena reaksi asam lemak bebas dengan alkali [21].

Pada saat ini teknologi sabun telah berkembang pesat. Sabun dengan jenis dan bentuk yang bervariasi dapat diperoleh dengan mudah dipasaran seperti sabun mandi, sabun cuci baik untuk pakaian maupun untuk perkakas rumah tangga, hingga sabun yang digunakan dalam industri.

Sabun merupakan bahan logam alkali dengan rantai asam monocarboxylic yang panjang.Larutan alkali yang digunakan dalam pembuatan sabun bergantung pada jenis sabun tersebut.Larutan alkali yang biasa yang digunakan pada sabun keras adalah Natrium Hidroksida $(\mathrm{NaOH})$ dan alkali yang biasa digunakan pada sabun lunak adalah Kalium Hidroksida (KOH) [13].

Dalam pembuatan sabun, ada beberapa faktor yang harus diperhatikan. Adapun faktor - factor yang mempengaruhi proses pembuatan sabun adalah [13]:

\section{Konsentrasi larutan Alkali}

Konsentrasi alakali yang digunakan dihitung berdasarkan stokiometri reaksi, dimana penambahan minyak harus sedikir berlebih agar sabun yang terbentuk tidak memiliki nilai alkali bebas berlebih. Alkali terlalu pekat akan menyebabkan terpecahnya emulsi pada larutan sehingga fasenya tidak homogen, sedangkan jika alkali yang digunakan terlalu encer, maka reaksi akan membutuhkan waktu yang lebih lama.

\section{Suhu}

Ditinjau dari segi termodinamikan, kenaikan suhu akan menurunkan rendemen sabun, hal ini dapat dilihat dari persamaan (1) berikut:

$$
\frac{\mathrm{d} \ln \mathrm{K}}{\mathrm{dT}}=\frac{\Delta \mathrm{H}}{\mathrm{RT}} .
$$

Karena reaksi penyabunan merupakan reaksi eksotermis ( $\Delta \mathrm{H}$ negatif), maka dengan kenaikan suhu akan dapat memperkecil harga $\mathrm{K}$ (konstanta keseimbangan), tetapi jika ditinjau dari segi kinetika, kenaikan suhu akan menaikan kecepatan reaksi.

3. Pengadukan

Pengadukan dilakukan untuk memperbesar probobalitas interaksi molekul-molekul reaktan yang bereaksi.Jika interaksi antar molekul reaktan semakin besar, maka kemungkinan terjadinya reaksi semakin besar pula. Hal ini sesuai dengan persamaan Arhenius dimana konstanta kecepatan reaksi k akan semakin besar dengan semakin sering terjadinya interaksi yangdisimbolkan dengan konstanta $\mathrm{A}$.

4. Waktu 
Semakin lama waktu reaksi menyebabkan semakin banyak pula minyak yang dapat tersabunkan, berarti hasil yang didapat juga semakin tinggi, tetapi jika reaksi telah mencapai kondisi setimbangnya, penambahan waktu tidak akan meningkatkan jumlah minyak yang tersabunkan [10].

\section{Metodologi Penelitian \\ Bahan Baku dan Peralatan}

Bahan yang digunakan antara lain aquadest, alkohol, $\mathrm{KOH}$, asam klorida, asam sulfat, indikator jingga metal, indikator phenolpthalein, minyak kelapa, dan $\mathrm{NaOH}$.

Adapun peralatan yang digunakan yaitubeaker glass, cawan petri, erlenmeyer, hot plate, klem + statif + buret, Beaker glass, Pengaduk multiple pitch blade turbine, neraca digital, oven, refluks kondensor, termometer, dan labu leher tiga.

\section{Pemeriksaan Bilangan Penyabunan}

Analisis bilangan penyabunan dilakukan dengan sampel minyak ditimbang sebanyak \pm 2 gram dan ditambahkan $25 \mathrm{~mL} \mathrm{KOH}$ alkoholis 0,5 N. Campuran dimasukkan kedalam labu leher tiga yang dihubungkan dengan refluks condensor dan dipanaskan di atas hot plate sambil diaduk menggunakan stirer selama 60 menit.Selanjutnya, larutan dimasukkan ke dalam erlenmeyer, Indikator phenolfthalein di tambah sebanyak 2 tetes dan larutan diititrasi dengan $\mathrm{HCl}$ 0,5 $\mathrm{N}$ sampai warna berubah menjadi tidak berwarna. Bilangan penyabunan dihitung dengan rumus [2] :

Bilangan penyabunan $=\frac{\left(\mathrm{V}_{0}-\mathrm{V}_{1}\right) \times \mathrm{N} \times \mathrm{BM}}{\mathrm{M}}$

Keterangan:

$\begin{array}{ll}\mathrm{V}_{0} & =\text { volume titrasi blanko } \\ \mathrm{V}_{1} & =\text { volume titrasi sampel } \\ \mathrm{N} & =\text { normalitas } \mathrm{HCl} \\ \mathrm{BM} & =\text { berat molekul } \mathrm{KOH} \\ \mathrm{M} & =\text { berat sampel }\end{array}$

\section{Prosedur Saponifikasi}

Minyak kelapa sebanyak 1118 gram di panaskan pada suhu $60^{\circ} \mathrm{C}, 70^{\circ} \mathrm{C}$ dan $80{ }^{\circ} \mathrm{C}$. Larutan $\mathrm{NaOH} 30 \%$ dibuat sebanyak 556,68 gram.Larutan $\mathrm{NaOH}$ ditambahkan dalam minyak kelapa yang telah di panaskan secara perlahanlahan.Larutan diaduk menggunakan multiple pitch blade turbine dengan kecepatan 300rpm, 400rpm, dan 500 rpm dengan waktu reaksi 45 menit, 60menit dan 75 menit.

\section{Pemeriksaan Kadar Air pada Sabun}

Pemeriksaan kadar air pada sabun dapat dilakukan sebagai berikut :

Cawan petri kosong ditimbang sehingga didapatkan beratnya5 gram sabun dimasukkan dan dioven pada suhu $105^{\circ} \mathrm{C}$ selama 1 jam Kemudian dilakukan penimbangan setiap 5 menit untuk memastikan bahwa kandungan air telah sepenuhnya menguap yang ditandai dengan berat sabun yang konstan.Langkah selanjutnya adalah menimbang cawan petri yang berisi sabunyang telah kering agar didapatkan beratnya. Kadar air dhitung dengan rumus [2]:

Kadar air $(\%)=\frac{w_{2-w_{1}}}{\text { Berat sabun }} \times 100$

Keterangan :

$\mathrm{W}_{1}=$ Berat sabun setelah pengeringan

$\mathrm{W}_{2}=$ Berat sabun + cawan sebelum pengeringan

\section{Perhitungan Kadar Alkali Bebas}

Perhitungan alkali bebas dengan:

5 gram sabun ditimbang dan dimasukkan ke dalam erlenmeyer $250 \mathrm{ml}$. Alkohol netral ditambahkan sebanyak $25 \mathrm{ml}$ dan diaduk hingga homogeny, Phenolfthalein ditambahkan sebanyak 3 tetes. Larutan tersebut dititrasi menggunakan larutan $\mathrm{HCl} 0,1 \mathrm{~N}$ hingga warna merah jambunya hilang. Kadar alkali bebas dihitung dengan rumus[2]:

$\%$ alkali bebas $=\frac{\mathrm{V} \times \mathrm{N} \times \mathrm{BM}}{\mathrm{M}} \times 100 \%$

Keterangan:

$$
\begin{array}{ll}
\mathrm{V} & =\text { volume titrasi } \mathrm{HCl}(\mathrm{ml}) \\
\mathrm{N} & =\text { normalitas } \mathrm{HCl}(\mathrm{N}) \\
\mathrm{BM} & =\text { berat molekul } \mathrm{NaOH}(40 \mathrm{~g} / \mathrm{mol}) \\
\mathrm{M} & =\text { berat sabun }(\mathrm{g})
\end{array}
$$

\section{Pengukuran Derajat Keasaman (pH)}

Pengukuran derajat keasaman $(\mathrm{pH})$ dapat dilihat sebagai berikiut:

Sabun sebanyak 10 gram ditimbang dan dilarutkan dalam $100 \mathrm{ml}$ aquadest.Kemudian $\mathrm{pH}$ meter yang telah dikalibrasi/dinetralkan dicelupkan dalam larutan sabun. Hasil yang muncul dicatat[13].

\section{Hasil dan Pembahasan Bilangan Penyabunan}

Bedasarkan pengujian yang dilakukan untuk mengetahi kelakayakan dari bahan baku yang digunakan di peroleh bilangan penyabunan minyak kelapa adalah 256,2 .

Bilangan penyabunan adalah banyaknya alkali yang dibutuhkan untuk menyabunkan 
sejumlah minyak. Semakin tinggi bilangan penyabunan menunjukkan semakin tinggi pula kadar asam lemak bebas pada minyak sehingga alkali yang dibutuhkan untuk menyabunkan minyak tersebut juga akan semakin banyak [20]. Sehingga semakin besar angka penyabunan maka asam lemak akan semakin kecil dan kualitas minyak akan semakin bagus, sebaliknya jika angka penyabunan kecil maka asam lemak besar dan kualitas menurun [6].

\section{Pengaruh Kondisi operasi Terhadap Derajat Keasaman (pH)}

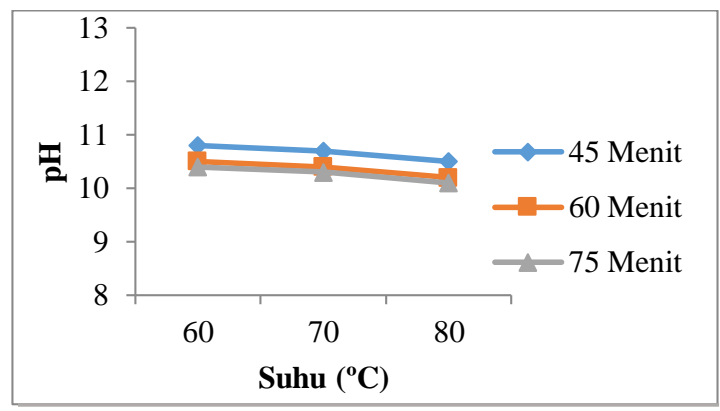

(a)

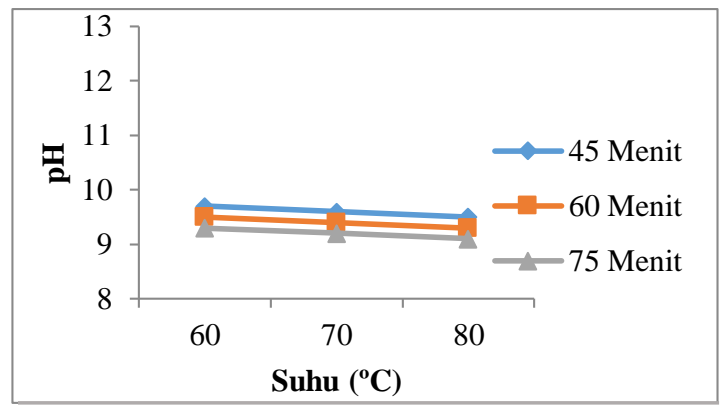

(b)

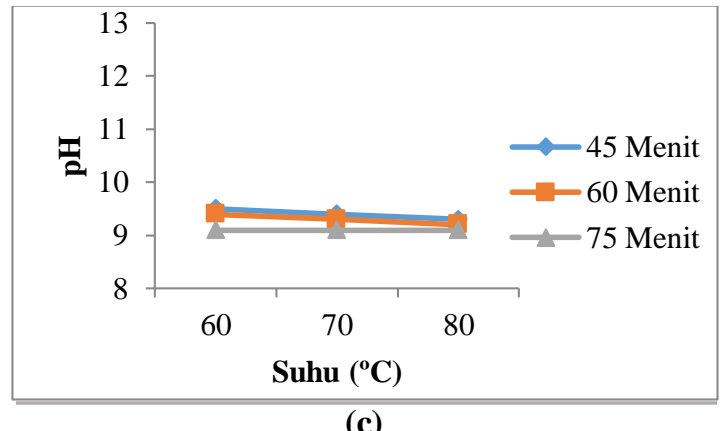

Gambar 1. Grafik Pengaruh Kondisi Operasi Terhadap Derajat Keasaman (pH)

Dari gambar dapat dilihat adanya pengaruh waktu pengadukan dan suhu reaksi pada kecepatan pengadukan $300 \mathrm{rpm}$ (a), $400 \mathrm{rpm}$ (b), $500 \mathrm{rpm}(\mathrm{c})$ terhadap $\mathrm{pH}$ sabun yang dihasilkan. Dengan semakin bertambahnya waktu pengadukan dapat menyebabkan turunnya $\mathrm{pH}$ sabun yang dihasilkan.Berdasarkan penelitian yang dilakukan oleh (Wijaya, 2009), nilai pH memiliki kecenderungan yang semakin menurun dengan semakin lamanya pengadukan [16]. Dan pengaruh suhu reaksi terhadap nilai $\mathrm{pH}$ sabun akan semakin turun seiring dengan semakin besar suhu reaksi. Pada kisaran suhu tertentu , kenaikan suhu akan mempercepat reaksi penyabunan, yang artinya menaikkan hasil dalam waktu yang lebih cepat. Tetapi jika kenaikan suhu telah melebihi suhu optimum, akan menyebabkan pengurangan hasil karena harga kesetimbangan konstanta reaksi $\mathrm{K}$ akan turun yang berarti reaksi akan bergeser kearah pereaksi atau dengan kata lain produk akan berkurang[1422].

$\mathrm{pH}$ merupakan indikator potensi iritasi pada sabun. pH sabun yang relatif basa dapat membantu kulit membuka pori-porinya kemudian busa dari sabun mengikat sabun dan kotoran lain yang menempel di kulit [17]. Sabun yang memiliki $\mathrm{pH}$ tinggi dapat meningkatkan pertumbuhan bakteri Propionibacterium dan membuat kering kulit.Hal ini terjadi karena sabun dengan $\mathrm{pH}$ tinggi dapat membengkakan keratin sehingga memudahkan masuknya bakteri yang menyebabkan kulit menjadi kering dan pecah-pecah, sementara sabun dengan $\mathrm{pH}$ terlalu rendah dapat menyebabkan iritasi pada kulit [7].

$\mathrm{pH}$ merupakan salah satu parameter yang penting dalam penentuan mutu sabun padat, karena nilai $\mathrm{pH}$ menentukan kelayakan sabun untuk digunakan sebagai sabun mandi. Sabun padat yang diperoleh pada penelitian ini memiliki pH antara 9,1 - 9,5. dan menurut SNI pH sabun padat berkisar antara 9 - 11. Jadi sabun yang diperoleh pada penelitian telah sesuai dan layak untuk digunakan.

Bedasarkan grafik hasil penilitian pengaruh suhu reaksi dan waktu reaksi terhadap $\mathrm{pH}$ sabun padat dari minyak kelapa telah sesuai teori.

\section{Pengaruh Kondisi Operasi Terhadap Kadar Alkali}

Dari Gambar 2 dapat dilihat adanya pengaruh waktu pengadukan dan suhu reaksi pada kecepatan pengadukan $300 \mathrm{rpm}$ (a), $400 \mathrm{rpm}$ (b), 500 rpm (c) terhadap kadar alkali bebas. Dengan semakin bertambahnya waktu pengadukan dapat menyebabkan turunnya kadar kadar alkali bebas pada sabun yang dihasilkan. Sedangkan dengan semakin besarnya suhu reaksi penyabunan menyebabkan kadar alkali bebas pada sabun menurun sampai pada titik optimum. Hal ini disebabkan oleh semakin lamanya pengadukan maka waktu interaksi antara minyak dengan alkali akan semakin besar, maka reaksi akan mendekati kesetimbangan sehingga kadar alkali 
bebas pada sabun akan berkurang. [16]. Kecepatan mixing memiliki pengaruh yang cukup besar terhadap pembentukan sabun. Hal ini dikarenakan semakin cepat pengadukan yang dilakukan maka akan menggeser kesetimbangan reaksi kekanan yang akan semakin meningkatkan jumlah produk yang dihasilkan [7].

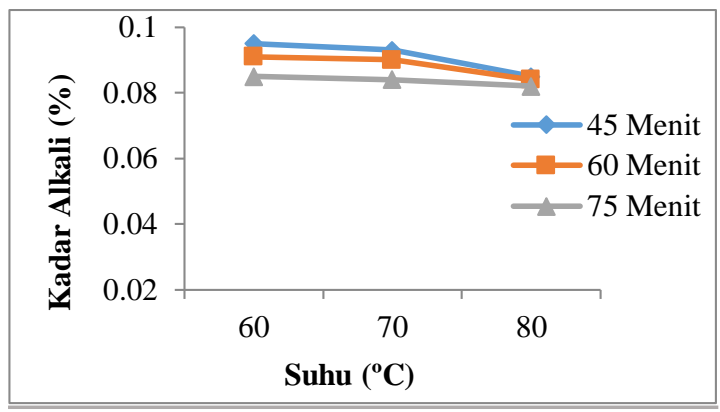

(a)

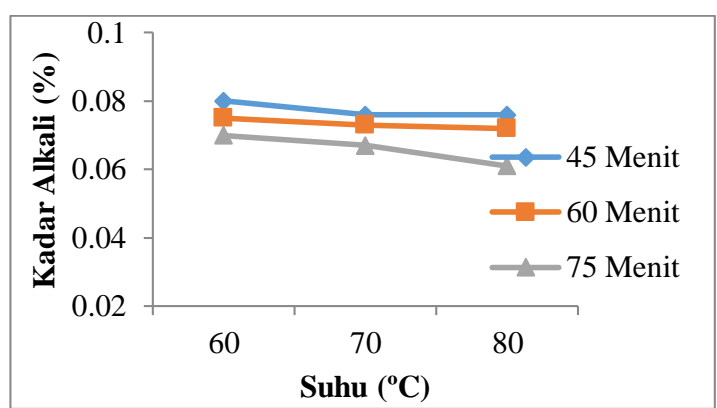

(b)

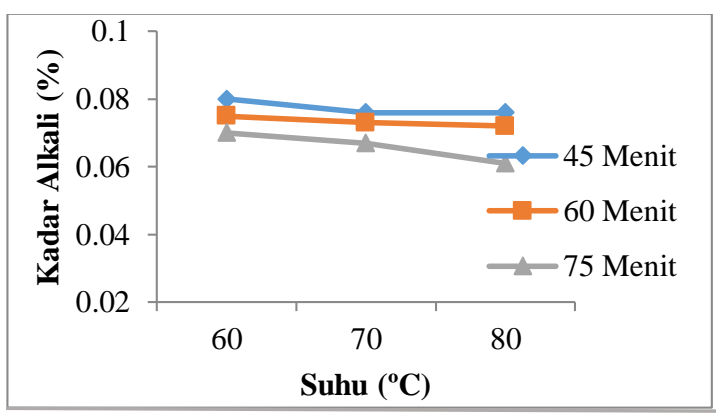

(c)

Gambar 2. Grafik Pengaruh Kondisi Operasi Terhadap Kadar Alkali

Kadar alkali menentukan kelayakan sabun untuk digunakan sebagai sabun mandi. Sabun padat yang diperoleh pada penelitian ini memiliki kadar alkali antara 0,03 - 0,095. Bedasarkan SNI nilai maksimum untuk kadar alkali sabun padat adalah 0,1 , jadi sabun yang diperoleh pada penelitian telah sesuai dan layak untuk digunakan.

Bedasarkan grafik hasil penilitian pengaruh suhu reaksi, waktu reaksi terhadap kadar alkali sabun padat dari minyak kelapa telah sesuai dengan teori.

\section{Pengaruh Kondisi Operasi Terhadap Kadar} Air

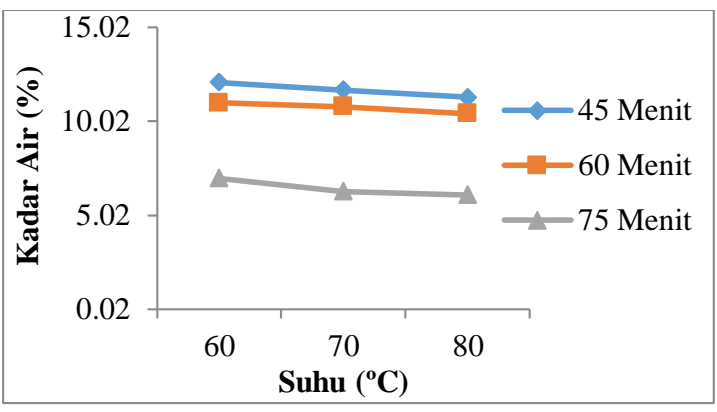

(a)

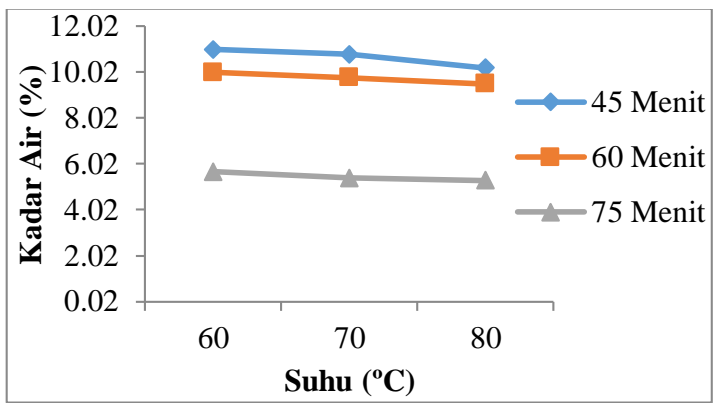

(b)

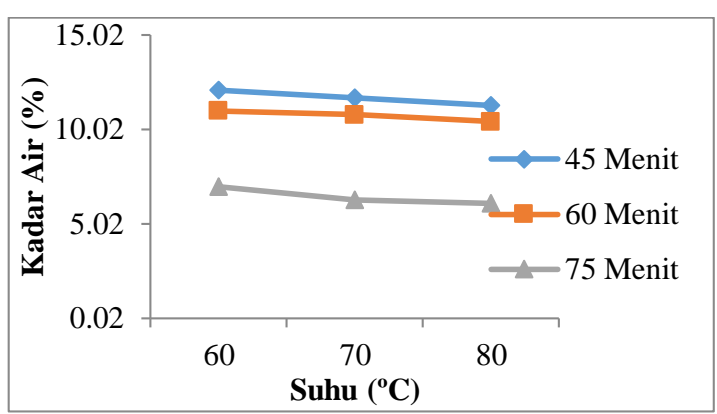

(c)

Gambar 3. Grafik Pengaruh Kondisi Operasi Terhadap Kadar Air

Dari gambar dapat dilihat adanya pengaruh waktu pengadukan dan suhu reaksi pada kecepatan pengadukan $300 \mathrm{rpm}$ (a), $400 \mathrm{rpm}$ (b), 500 rpm (c) terhadap kadar air. Dengan semakin lama waktu pengadukan maka semakin rendah kadar air yang dihasilkan [15]. Semakin tinggi suhu akan menyebabkan kandungan air menguap, air yang menguap menyebabkan sabun menjadi kering [4].

Kecepatan mixing memiliki pengaruh yang cukup besar terhadap pembentukan sabun. Hal ini dikarenakan semakin cepat pengadukan yang dilakukan maka akan menggeser kesetimbangan reaksi kekanan yang akan semakin meningkatkan jumlah produk yang dihasilkan [7]. Semakin tinggi suhu akan menyebabkan kandungan air 
menguap, air yang menguap menyebabkan sabun menjadi kering [18].

Kadar air mempengaruhi kekerasan sabun, sabun dengan kadar air rendah akan sukar larut dan dapat merusak kulit [9] dan Banyaknya kadar air dapat mempengaruhi kelarutan sabun dalam air pada saat digunakan. Apabila kandungan air pada sabun terlalu tinggi akan menyebabkan sabun mudah menyusut dan tidak nyaman saat digunakan [23].

Kadar air merupakan jumlah kadar air yang terkandung dalam bahan. Menurut standar SNI bahwa jumlah kadar air yang diperbolehkan maksimal 15\%, kadar air merupakan salah satu parameter yang penting dalam penentuan mutu sabun padat, karena kadar alkali menentukan kelayakan sabun untuk digunakan sebagai sabun mandi. Sabun padat yang diperoleh pada penelitian ini memiliki kadar air antara 6,1212,10. Maka, sabun yang diperoleh pada penelitian telah sesuai dan layak untuk digunakan.

Bedasarkan grafik hasil penilitian pengaruh suhu reaksi, waktu reaksi terhadap kadar air sabun padat dari minyak kelapa telah sesuai dengan teori.

\section{KESIMPULAN}

Kesimpulan dari penelitian ini adalah kondisi operasi terbaik diperoleh pada suhu $70^{\circ} \mathrm{C}$, waktu reaksi 60 menit, kecepatan pengadukan $400 \mathrm{rpm}$ dengan nilai $\mathrm{pH}$ 9,4 dan kadar alkali 0,073 serta kadar air 9,8.

\section{Daftar Pustaka}

[1] A. Manikandan, R. Meera, dan E. Kannan, Cold Pressed Virgin Coconut Oil From Full Fat Coconut Flakes a Funcional Oil, International Journal of Pharmacy and Pharmaceutical Sciences, 6(6) (2014).

[2] Badan Standarisasi Nasional, 1994, Standar Mutu Sabun Mandi, SNI 06-3532-1994, Dewan Standarisasi Nasional, Jakarta.

[3] B.Laura, M. Aline, B. Fernanda, B. Catarina, B.A.G. Catarina, Effect of Coconut Oil on Human Health, Open Journal of Endocrine and Metabolic Diseases, (2015) 84-87.

[4] Edy, Pengaruh Lama Waktu Pengadukan Terhadap Kualitas Minyak Kelapa Murni (VCO) Yang Dihasilkan, Skripsi, Program Studi Teknologi pengolahan Hasil Perkebunan, Jurusan Pengolahan Hasil Hutan, Politeknik Negeri Samarinda (2010).

[5] G. K. Pronir, B. Paramita, M. Mitra, P. S. Mousumi, Physicochemical and
Phytochemical Analyses of Copra and Oil of Cocos nucifera L, (West Coast Tall Variety), International Journal of Food Science, (2014).

[6] H. Wijayanti, H. Nora, R. Amelia, Pemanfaatan Arang Aktif dari Serbuk Gergaji Kayu Ulin untuk Meningkatkan Kualitas Minyak Goreng Bekas, Konversi, 1(1) (2012), 27-33.

[7] K. F. Perdana, I. Hakim, Pembuatan Sabun Cair dari Minyak Jarak dan Soda Q Sebagai Upaya Meningkatkan Nilai Paasar Soda Q, Skripsi. Jurusan Teknik Kimia, Fakultas Teknik, Universitas Diponegoro, (2010).

[8] L. A. Yunita, Pengaruh temperatur dan Kecepatan pengadukan Sludge Industri Minyak Kelapa Sawit untuk Pembuatan Sabun Cair, Skirpsi, Program Studi Teknik Kimia, Politeknik Sriwijaya, 2014.

[9] M. Maulana, Pengaruh Suhu dan Waktu Penyimpanan Sabun Mandi Batang Kecantikan dan Sabun Mandi Batang kesehaatn Terhadao Kadar Air, Alkali Bebas $\mathrm{NaOH}$, Asam Lemak Bebas, dan Kadar Garam NaCl, Skripsi, Program Studi Kimia S1 Ekstensi, Departemen Kimia, Fakultas Matematika dan Ilmu Pengetahuan Alam, Universitas Sumatera Utara, 2008.

[10] Naomi. P, Lumbangaol. A. M, Toha M. Y, Pembuatan Sabun Lunak dari Minyak Goreng Bekas Ditinjau dari Kinetia Reaksi Kimia, Jurnal Teknik Kimia, Jurusan Teknik Kimia, Fakultas Teknik, Universitas Sriwijaya, Palembang, (2013).

[11] Orhevba, B.A, Chukwu, O., Oguagwu, V., Osunde, Z.D, Effect of Moisture Content on some Quality Parameters of Mechanically Expressed Neem Seed Kernel Oil, The International Journal Of Engineering And Science (IJES), 2(8) (2013).

[12] P.WNur, Pengaruh Agitasi Mekanik terhadap Proses Presipitasi $\mathrm{CaCO} 3$ pada Air Sadah, Skripsi. Departemen Teknik Kimia, Fakultas Teknik Universitas Indonesia, 2011.

[13] Q. Rachmiati, Sifat Kimia Sabun Transparan dengan Penambahan Madu Pada Konsentrasi yang Berbeda, Skripsi, Proggram Studi Teknologi Hasil Ternak, Fakultas Peternakan, Institur Pertanian Bogor, Bogor, 2009.

[14] Ravi, M. R. Jhalani, Anurag, Sinha, Sanjiv, Ray, Anjan, Development of a semiempirical model for pyrolysis of an annular sawdust bed, Jurnal Analysis Application Pyrolysis, 71 (2004), 353-374.

[15] R. Rizka, Formulasi Sabun Padat Kaolin Penyuci Najis Mughalladzah dengan 
Variasi Konsentrasi Minyak Kelapa dan Asam Stearat, Skripsi, Program Studi Farmasi, Fakultas kedokteran dan Ilmu Kesehatan UIN Syarif Hidayatullah Jakarta, 2017.

[16] S. T Indah, Kasih, J. P Sari, T. J. N Sari, Pembuatan Sabun Padat dan Sabun Cair dari Minyak Jarak, Jurnal Teknik Kimia, Universitas Sriwijaya, 17(1) (2010).

[17] S. T Indah, Herdiana, E. Herdiana, A. Triana, Pembuatan VCO dengan Metode Enzimatis dan Konversinya Menjadi Sabun Padat Transparan, Jurnal Teknik Kimia, Universitas Sriwijaya, 17(3) (2010),

[18] S. Padmini, A. Suman, T. Alexandra, Coconut oil:a review, Agro Food Industry Hi Tech, 24(5), (2014).

[19] U.I.D Ayu, W.R. Pertiwi, Pembuatan Sabun Transparan dari Minyak Kelapa Murni (Virgin Coconut oil), Skripsi, Program Studi Diploma III Teknik Kimia, Fakultas Teknik, Universitas Sebelas Maret : Surakarta, 2012.

[20] W. M Stanlay, Chemical Process Equipment Selection and Design, Department of Chemical and Petroleum Engineering, University of Kansas, 1990.

[21] W. Susinggih, T. Harnawati, Studi Pembuatan Sabun Mandi Cair Dari Daur Ulang Minyak Goreng Bekas (Kajian Lama Pengadukan Dan Rasio Air : Sabun Terhadap Kualitas), Jurnal Teknologi Peratian, 10(1), (2009).

[22] Y. Sukawaty, H. Warnida, A. V. Verranda Artha, Formulasi Sediaan Sabun Mandi Padat Ekstraksi Etanol Umbi Bawang Tiwai (Eleutherine bulbosa (Mill.) Urb.), Skripsi, Akademi Farmasi Samarinda, Samarinda, 2016. 